\title{
A Comparative Study of Two Chemo-Radiation Regimens for the Cancer of Larynx
}

\author{
Sharad Singh ${ }^{1 *}$, S N Prasad ${ }^{2}$, Mangesh Korde², Sunny Kumar², Aditya Elhence², \\ Vaibhav Shakya ${ }^{2}$
}

\begin{abstract}
The region of head and neck is critical for respiration, nutrition, and speech. The management of laryngeal tumours can stimulate mutilations and cosmetic deformities and worsen the life. A "non-operative approach" is preferred for patients to whom radiation following surgery, possibly, will direct severe functional destruction predominantly in advanced stage patients having a bulk of carcinoma larynx. The case material for the study was selected from the cross-section of patients registered at the J. K. Cancer Institute, Kanpur. Histologically squamous cell carcinoma 64 patients were registered and equally and randomly placed into Arm I and Arm II. "Arm I" patients and "Arm II" was comprised of randomly selected 64 patients, having histopathologically proven squamous cell carcinoma of the larynx. All patients (32 patients) belonging to "Arm I" received concurrent chemoradiotherapy of Inj. Cisplatin $100 \mathrm{mg} / \mathrm{m}^{2}$ for three-weekly underwent EBRT with $60 \mathrm{Co} / \mathrm{LINAC}$ and photon radiation of $70 \mathrm{~Gy}$ in 35 fractions for 7 weeks ( 2 parallel opposed fields). All the patients (32 patients) belongs to "Arm II" received chemo boost as Inj. Cisplatin 6 $\mathrm{mg} / \mathrm{m} 2$ on last 15 fractions of treatment underwent EBRT with $60 \mathrm{Co} / \mathrm{LINAC}$ photon radiation of $70 \mathrm{~Gy}$ in 35 fractions for 7 weeks. Radiotherapy was delivered in supine position by parallel opposing fields including the primary tumour, disease extension, and neck nodes. The study concluded that the loco-regional responses are analogous in Arm I and Arm 2, however Arm II had additional treatment allied toxicities and resulting from numerous of treatment breaks.
\end{abstract}

Keywords: Photon radiation- EBRT- chemo-radiation regimens- chemoradiotherapy

Asian Pac J Cancer Prev, 19 (11), 3265-3270

\section{Introduction}

Annually 686,328 head and neck cancer cases are diagnosed world-wide which is $4.8 \%$ of all cancers and deaths due to head and neck cancer are 375,665 which is $4.6 \%$ of all cancers (Barbara et al., 2014). In India, recently diagnosed head and neck cases are 145,087 annually, which are $14.3 \%$ of all cancers and deaths are 105,247 , which are $15.4 \%$ of all cancer deaths (Barbara et al., 2014; Ferlay et al., 2013). Head and neck cancer constitute malignancies of "oral cavity", "nasopharynx", "oropharynx", "hypopharynx, larynx", "paranasal sinuses", and "major and minor salivary glands" (Bose et al., 2013). Majority of them occur from the epithelial surface and are reported as squamous cell carcinomas (Bose et al., 2013). The 5-year survival for patients with Stage-I exceeds $80 \%$ but is $<40 \%$ in locally advanced head and neck carcinoma (Waes et al., 2014). Generally, for early-stage patients (Stage I or II) surgery or radiation is successful as single modality therapy, for most sites (Bose et al., 2013; Murphy, 2011).

Radiation may be more potent in eradicating the localized primary tumour, because it can be targeted specifically, and large doses may be given by Barbara et al., (2014). The region of head and neck contains the critical areas intended for, nutrition, respiration, one's expression. In the past 20 years, there has been great expansion in the use of radiotherapy (RT) with or without chemotherapy as a primary treatment modality for head and neck cancer (Robbins et al., 1994; Lefebvre 1996; Browman et al., 2001; Kies et al., 2001; Rosen et al., 2003; Vokes et al., 2003; Weber et al., 2003; Kitamoto et al., 2005; Allal et al., 2006; Allen et al., 2007; Moyer et al., 2004). Even though the primary objective of treatment is to cure, an alleged benefit of modality is to the preserve the organs of the head and neck, with the essential assumption being that protection of structure will be upshot in the perpetuation of function (Schwarz et al., 2004). The existing literature on ingurgitation function in patients treated with RT with chemotherapy or devoid of chemotherapy for head and neck cancer, indicates that, despite preservation of the head and neck structures, swallow function is no longer maintained at regular levels after treatment (Barbara et al., 2014). Laryngeal tumours 
management by treatments may stimulate supplementary mutilations and cosmetic deformities, deteriorate the excellence of life. A non-operative strategy is favoured for patients in which surgical treatment accompanied via radiation may additionally lead to extreme functional impairment specifically in vicinity where the bulk of carcinoma larynx patients are in the advanced stages.

Preferably, the advanced stages of carcinoma larynx are treated via combined modality treatment in the form of chemo-radiation This study has lead us to explore the promising schedules of "radio sensitizing concurrent chemotherapy" as a step to augment local control in "locally advanced carcinoma larynx".

\section{Materials and Methods}

\section{Subjects and Methodology}

The case material for the study was selected from the cross-section of patients registered at the J. K. Cancer Institute, Kanpur, India. 64 patients with squamous cell carcinoma of head and neck were registered and equally and randomly placed into Arm I and Arm II. "Arm I" patients and "Arm II" comprised of randomly selected 64 patients, having histopathological proven squamous cell carcinoma of the larynx.

\section{Pre-treatment assessments to appraise the exclusion and} inclusion criteria

The pre-treatment assessment included the complete history, general physical examination, and complete systemic examination and estimation of Body surface area (BSA). General condition assessment depends on Karnofsky Performance Status; Hematologic assessment: including haemoglobin, total leukocyte count (TLC), differential leukocyte count (DLC) and platelet count; Biochemical assessment: estimation of blood urea, serum creatinine, SGOT and SGPT levels (assess the kidney and liver function); Radiological assessment: X-ray chest and X-ray soft tissues of neck-lateral view; Accurate staging determination on clinical indication: by laryngoscopy, USG-abdomen and pelvis and computed tomography scan of face and neck. The patients were staged according to AJCC (American Joint Committee on Cancer) 2010 staging system.

Through Pre-treatment assessment, the inclusion criteria of patients for the study were dependents on "Histologically proven Squamous cell carcinoma"; "Karnofsky Performance Status > 70"; "Complete hemogram with $\mathrm{Hb}>8 \mathrm{gm} / \mathrm{dL}$ "; "TLC $>4000 / \mathrm{cmm}$, Platelet count $>100,000 / \mathrm{cmm}$ "; "Renal function tests with Blood urea $<40 \mathrm{mg} / \mathrm{dL}$ and Serum creatinine $<1.5 \mathrm{mg} / \mathrm{dL}$ "; "Liver function tests with SGOT $<35$ IU/L and SGPT $<40$ IU/L"; "AJCC stage non metastatic carcinoma of larynx". The patients having conditions of "Distant metastases"; "Prior radiation, surgery or chemotherapy for the disease"; "Poor general condition with Karnofsky Performance Status of $<70$ "; "Pregnant or lactating patient"; "Associated medical condition such as renal disease, disease or heart disease"; "Patients with primary thyroid / salivary glands"; "Histopathology other than squamous cell carcinoma" were excluded from the study.
All patients (32 patients) belonging to "Arm I" received concurrent chemoradiotherapy of Inj. Cisplatin $100 \mathrm{mg} / \mathrm{m}^{2}$ for three-weekly underwent EBRT with 60 $\mathrm{Co} / \mathrm{LINAC}$ and photon radiation of $70 \mathrm{~Gy}$ in 35 fractions for 7 weeks ( 2 parallel opposed fields). All the patients (32 patients) belonging to "Arm II" received chemo boost as Inj. Cisplatin $6 \mathrm{mg} / \mathrm{m}^{2}$ on last 15 fractions of treatment underwent EBRT with $60 \mathrm{Co} / \mathrm{LINAC}$ photon radiation of $70 \mathrm{~Gy}$ in 35 fractions for 7 weeks.

\section{Radiotherapy technique}

Radiotherapy was delivered in supine position by parallel opposing field including the primary tumour, disease extension and neck nodes. Radiation reactions were assessed by Radiation Therapy Oncology Group (RTOG) criteria and WHO toxicity criteria. Radiation Therapy Oncology Group (RTOG) acute morbidity scoring criteria were pertinent from day 1 , the commencement of radiation, through day 90 and thereafter, the RTOG criteria for late effects were utilized tumour response (both primary and nodal response) was assessed by WHO response criteria.

From the beginning of treatment, all the patients integrated into the study were carefully and regularly assessed daily during treatment and weekly during planned gaps in treatment. Complete clinical assessment for the tolerance of each patient to the delivered treatment was done by local examination of the patient for local disease status along with observation of acute toxic side effects of radiation. The acute morbidity criteria are used to score/grade toxicity from radiation therapy. The criteria are relevant from day 1, the commencement of therapy, through day 90 . Then, the EORTC/RTOG criteria of late effects are to be utilized. The evaluator must attempt to categorize between disease and treatment allied signs and symptoms. An accurate baseline assessment earlier to initiation of therapy is essential. All toxicities grade 3, 4 or $5 *$ need to be verified by the Principal Investigator.

All the patients were assessed after the complete treatment for two weeks, to identify discriminating complications akin to mucositis, skin reaction. Acute treatment allied toxicity was graded using general terminology criteria for unfavourable actions (RTOG) and delayed toxicity by criteria of RTOG. The response of tumour was assessed by via the WHO criteria. Assessments related to Radiology for tumour was made while indicated.

\section{Follow up}

All the patients were followed up regularly on the bases of OPD least for six months, weekly in the first month and once in a month. At every visit, each patient was clinically evaluated for local control of disease and treatment related complications. The patients were assessed for any evidence of distant metastasis on each follow-up. To evaluate the local disease control, local examination using inspection, palpation etc. was done at each follow up and response was assessed. On the suspicion of any local recurrence, biopsy was taken for histopathology and correlated clinically. To evaluate the distant metastasis detailed history pertaining to any symptoms was taken and general physical examination of patients was done. 
In case of suspicion, relevant investigations were done to rule out the presence of distant metastasis. The QOL was assessed at the beginning of treatment, on the day of completion of treatment and one month after completion of planned treatment using University of Washington QOL questionnaire. The results of the study regarding safety, tolerability, toxicity and response in all the groups were documented.

\section{Statistical analysis}

The data consequently obtained was assessed, analysed and compared to find dissimilarity in the entire arms in the basis of response of tumour and life's quality. The chi-square test of significance was applied to establish whether the observed outcomes are statistically momentous or not.

\section{Results}

The major objective of the study was to evaluate histopathologically proven advanced stage of squamous cell carcinoma larynx patients and randomly divides into two arms to evaluate "loco-regional response", "acute and chronic toxicities". Therefore, the study explored the available Medical Literature and correlates the outcome of the study to validate the feasibility of the present study.

In this study overall, 62 patients were males and 2
Table 1. General Information of Patients Distribution in Arm I and Arm II

\begin{tabular}{lcc}
\hline Properties & Arm I & Arm II \\
\hline Total patients & 32 & 32 \\
Patient gender ratio(M/F) & $31 / 1$ & $31 / 1$ \\
Age group & & \\
$\quad<30$ & 0 & 0 \\
$\quad 31-40$ & 2 & 2 \\
$41-50$ & 8 & 11 \\
$51-60$ & 15 & 14 \\
$61-70$ & 4 & 3 \\
$\quad>70$ & 3 & 2 \\
Background of patient & & \\
$\quad$ Rural (50)/Urban (14) & $26 / 8$ & $24 / 6$ \\
\hline
\end{tabular}

patients were females. Overall, 50 patients were belongs to rural area, whereas 14 patients belong to urban background. In this study, 37 patients were smokers, whereas 16 patients were tobacco and panmasala addict and 8 patients was addict of both the habits. Out of the total enrolled patients 16 patients that was addict behavior belongs 1-10years of age group, 18 belongs to the age group of 11-20 and remaining patients were above the age group of 20years (Figure 1). The response of treatment for Arms I and Arm II was assessed 2 month

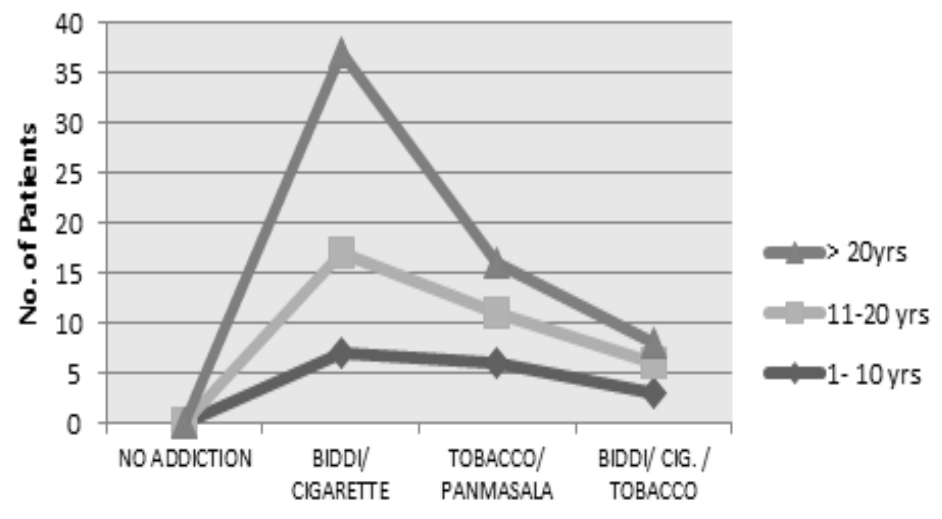

Figure 1. Graph Showing Distribution of Cases According to Addiction Habits

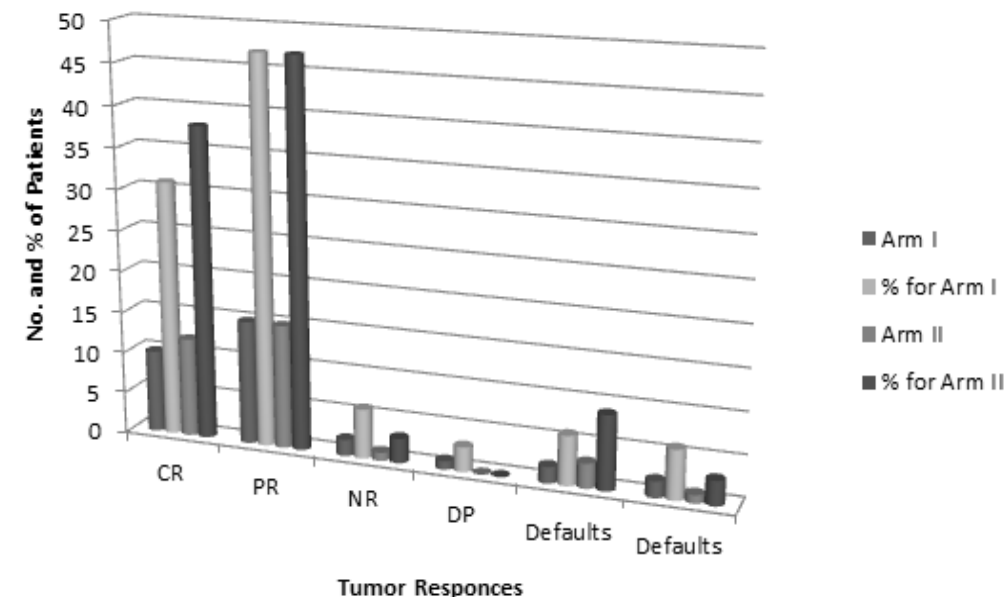

Figure 2. Tumor Responses in Arm I and Arm II 
Table 2. The Effect of Various Reaction, Condition and Glands on Diagnosed Patients Equally Distributed in Two Separate Arms

\begin{tabular}{|c|c|c|c|c|c|c|c|c|c|c|}
\hline \multicolumn{11}{|c|}{ (A) Active skin reaction } \\
\hline Weeks & Grade 0 & Grade 0 & Grade 1 & Grade 1 & Grade 2 & Grade 2 & Grade 3 & Grade 3 & Grade 4 & Grade 4 \\
\hline & ARM I & ARM II & ARM I & ARM II & ARM I & ARM II & ARM I & ARM II & ARM I & ARM II \\
\hline I & $13 / 32$ & $15 / 32$ & $15 / 32$ & $16 / 32$ & $3 / 32$ & $3 / 32$ & $0 / 32$ & $0 / 32$ & $0 / 32$ & $0 / 32$ \\
\hline II & $8 / 32$ & $8 / 32$ & $12 / 32$ & 9/32 & $5 / 32$ & $5 / 32$ & $0 / 32$ & $0 / 32$ & $0 / 32$ & $0 / 32$ \\
\hline III & $6 / 32$ & $5 / 32$ & $16 / 32$ & $15 / 32$ & $18 / 32$ & $17 / 32$ & $5 / 32$ & $5 / 32$ & $0 / 64$ & $0 / 32$ \\
\hline IV & $3 / 32$ & $2 / 32$ & $12 / 32$ & $18 / 32$ & $19 / 32$ & $22 / 32$ & $8 / 32$ & $11 / 32$ & $2 / 32$ & $1 / 32$ \\
\hline V & $1 / 32$ & $0 / 32$ & $9 / 32$ & $11 / 32$ & $10 / 32$ & $13 / 32$ & $4 / 32$ & $7 / 32$ & $1 / 32$ & $3 / 32$ \\
\hline VI & $0 / 32$ & $0 / 32$ & $8 / 32$ & $10 / 32$ & $8 / 32$ & $11 / 32$ & $5 / 32$ & $5 / 32$ & $0 / 32$ & $0 / 32$ \\
\hline$\%$ & $0 \%$ to $41 \%$ & $0 \%$ to $47 \%$ & $27 \%$ to $50 \%$ & $28 \%$ to $56 \%$ & $9 \%$ to $59 \%$ & $9 \%$ to $69 \%$ & $0 \%$ to $25 \%$ & $0 \%$ to $34 \%$ & $0 \%$ to $6 \%$ & $0 \%$ to $9 \%$ \\
\hline
\end{tabular}

(B) Laryngeal Reactions

$\begin{array}{ccccccccccc}\text { Weeks } & \text { Grade } 0 & \text { Grade } 0 & \text { Grade 1 } & \text { Grade 1 } & \text { Grade 2 } & \text { Grade 2 } & \text { Grade 3 } & \text { Grade 3 } & \text { Grade } 4 & \text { Grade } 4 \\ & \text { ARM I } & \text { ARM II } & \text { ARM I } & \text { ARM II } & \text { ARM I } & \text { ARM II } & \text { ARM I } & \text { ARM II } & \text { ARM I } & \text { ARM II } \\ \text { I } & 15 / 32 & 16 / 32 & 15 / 32 & 15 / 32 & 2 / 32 & 1 / 32 & 0 / 32 & 0 / 32 & 0 / 32 & 0 / 32 \\ \text { II } & 6 / 32 & 5 / 32 & 12 / 32 & 11 / 32 & 5 / 32 & 4 / 32 & 0 / 32 & 0 / 32 & 0 / 32 & 0 / 32 \\ \text { III } & 2 / 32 & 2 / 32 & 12 / 32 & 12 / 32 & 13 / 32 & 15 / 32 & 7 / 32 & 6 / 32 & 1 / 32 & 1 / 32 \\ \text { IV } & 2 / 32 & 2 / 32 & 14 / 32 & 18 / 32 & 19 / 32 & 21 / 32 & 5 / 32 & 8 / 32 & 1 / 32 & 1 / 32 \\ \text { V } & 1 / 32 & 2 / 32 & 9 / 32 & 11 / 32 & 8 / 32 & 9 / 32 & 5 / 32 & 6 / 32 & 2 / 32 & 3 / 32 \\ \text { VI } & 1 / 32 & 1 / 32 & 7 / 32 & 9 / 32 & 7 / 32 & 8 / 32 & 2 / 32 & 3 / 32 & 1 / 32 & 2 / 32 \\ \% & 3 \% \text { to } 47 \% & 3 \% \text { to } 50 \% & 22 \% \text { to } 47 \% & 28 \% \text { to } 56 \% & 4 \% \text { to } 59 \% & 3 \% \text { to } 65 \% & 0 \% \text { to } 22 \% & 0 \% \text { to } 25 \% & 0 \% \text { to } 4 \% & 0 \% \text { to } 9 \%\end{array}$

(C) Dysphagia

$\begin{array}{ccccccccccc}\text { Weeks } & \text { Grade } 0 & \text { Grade } 0 & \text { Grade 1 } & \text { Grade 1 } & \text { Grade 2 } & \text { Grade 2 } & \text { Grade 3 } & \text { Grade 3 } & \text { Grade } 4 & \text { Grade } 4 \\ & \text { ARM I } & \text { ARM II } & \text { ARM I } & \text { ARM II } & \text { ARM I } & \text { ARM II } & \text { ARM I } & \text { ARM II } & \text { ARM I } & \text { ARM II } \\ \text { I } & 17 / 32 & 13 / 32 & 13 / 32 & 15 / 32 & 1 / 32 & 3 / 32 & 0 / 32 & 0 / 32 & 0 / 32 & 0 / 32 \\ \text { II } & 5 / 32 & 8 / 32 & 15 / 32 & 12 / 32 & 4 / 32 & 5 / 32 & 0 / 32 & 0 / 32 & 0 / 32 & 0 / 32 \\ \text { III } & 3 / 32 & 6 / 32 & 12 / 32 & 16 / 32 & 12 / 32 & 18 / 32 & 8 / 32 & 5 / 32 & 1 / 32 & 0 / 64 \\ \text { IV } & 1 / 32 & 3 / 32 & 14 / 32 & 12 / 32 & 19 / 32 & 19 / 32 & 6 / 32 & 8 / 32 & 1 / 32 & 2 / 32 \\ \text { V } & 1 / 32 & 1 / 32 & 7 / 32 & 9 / 32 & 9 / 32 & 10 / 32 & 4 / 32 & 4 / 32 & 1 / 32 & 1 / 32 \\ \text { VI } & 1 / 32 & 0 / 32 & 7 / 32 & 8 / 32 & 7 / 32 & 8 / 32 & 2 / 32 & 5 / 32 & 1 / 32 & 0 / 32 \\ \% & 3 \% \text { to } 53 \% & 0 \% \text { to } 41 \% & 22 \% \text { to } 47 \% & 27 \% \text { to } 50 \% & 3 \% \text { to } 59 \% & 9 \% \text { to } 59 \% & 0 \% \text { to } 25 \% & 0 \% \text { to } 25 \% & 0 \% \text { to } 3 \% & 0 \% \text { to } 6 \%\end{array}$

(D) Salivary gland toxicity

$\begin{array}{ccccccccccc}\text { Weeks } & \text { Grade 0 } & \text { Grade 0 } & \text { Grade 1 } & \text { Grade 1 } & \text { Grade 2 } & \text { Grade 2 } & \text { Grade 3 } & \text { Grade 3 } & \text { Grade 4 } & \text { Grade } 4 \\ & \text { ARM I } & \text { ARM II } & \text { ARM I } & \text { ARM II } & \text { ARM I } & \text { ARM II } & \text { ARM I } & \text { ARM II } & \text { ARM I } & \text { ARM II } \\ \text { I } & 15 / 32 & 15 / 32 & 16 / 32 & 15 / 32 & 3 / 32 & 1 / 32 & 0 / 32 & 0 / 32 & 0 / 32 & 0 / 32 \\ \text { II } & 8 / 32 & 5 / 32 & 9 / 32 & 14 / 32 & 5 / 32 & 4 / 32 & 0 / 32 & 0 / 32 & 0 / 32 & 0 / 32 \\ \text { III } & 5 / 32 & 3 / 32 & 15 / 32 & 18 / 32 & 17 / 32 & 13 / 32 & 5 / 32 & 10 / 32 & 0 / 32 & 1 / 32 \\ \text { IV } & 2 / 32 & 0 / 32 & 18 / 32 & 17 / 32 & 22 / 32 & 18 / 32 & 11 / 32 & 8 / 32 & 1 / 32 & 2 / 32 \\ \text { V } & 0 / 32 & 0 / 32 & 11 / 32 & 15 / 32 & 13 / 32 & 13 / 32 & 7 / 32 & 7 / 32 & 3 / 32 & 3 / 32 \\ \text { VI } & 0 / 32 & 0 / 32 & 10 / 32 & 11 / 32 & 11 / 32 & 9 / 32 & 5 / 32 & 6 / 32 & 0 / 32 & 1 / 32 \\ \% & 0 \% \text { to } 47 \% & 0 \% \text { to } 47 \% & 28 \% \text { to } 56 \% & 32 \% \text { to } 56 \% & 9 \% \text { to } 69 \% & 3 \% \text { to } 56 \% & 0 \% \text { to } 34 \% & 0 \% \text { to } 3 \% & 0 \% \text { to } 9 \% & 0 \% \text { to } 9 \%\end{array}$

(E) Haematological toxicity

\begin{tabular}{ccccccccccc} 
Weeks & Grade 0 & Grade 0 & Grade 1 & Grade 1 & Grade 2 & Grade 2 & Grade 3 & Grade 3 & Grade 4 & Grade 4 \\
& ARM I & ARM II & ARM I & ARM II & ARM I & ARM II & ARM I & ARM II & ARM I & ARM II \\
I & $23 / 32$ & $22 / 32$ & $9 / 32$ & $10 / 32$ & $0 / 32$ & $0 / 32$ & $0 / 32$ & $0 / 32$ & $0 / 32$ & $0 / 32$ \\
II & $13 / 32$ & $12 / 32$ & $11 / 32$ & $12 / 32$ & $4 / 32$ & $4 / 32$ & $0 / 32$ & $0 / 32$ & $0 / 32$ & $0 / 32$ \\
III & $10 / 32$ & $10 / 32$ & $13 / 32$ & $12 / 32$ & $10 / 32$ & $11 / 32$ & $4 / 32$ & $4 / 32$ & $1 / 32$ & $1 / 32$ \\
IV & $5 / 32$ & $7 / 32$ & $14 / 32$ & $14 / 32$ & $12 / 32$ & $12 / 32$ & $5 / 32$ & $6 / 32$ & $1 / 32$ & $1 / 32$ \\
V & $2 / 32$ & $1 / 32$ & $15 / 32$ & $16 / 32$ & $12 / 32$ & $12 / 32$ & $6 / 32$ & $7 / 32$ & $2 / 32$ & $2 / 32$ \\
VI & $1 / 32$ & $1 / 32$ & $17 / 32$ & $17 / 32$ & $13 / 32$ & $14 / 32$ & $7 / 32$ & $7 / 32$ & $2 / 32$ & $2 / 32$ \\
$\%$ & $3 \%$ to $72 \%$ & $3 \%$ to $69 \%$ & $28 \%$ to $53 \%$ & $31 \%$ to $52 \%$ & $0 \%$ to $40 \%$ & $0 \%$ to $44 \%$ & $0 \%$ to $22 \%$ & $0 \%$ to $22 \%$ & $0 \%$ to $6 \%$ & $0 \%$ to $6 \%$ \\
\hline
\end{tabular}




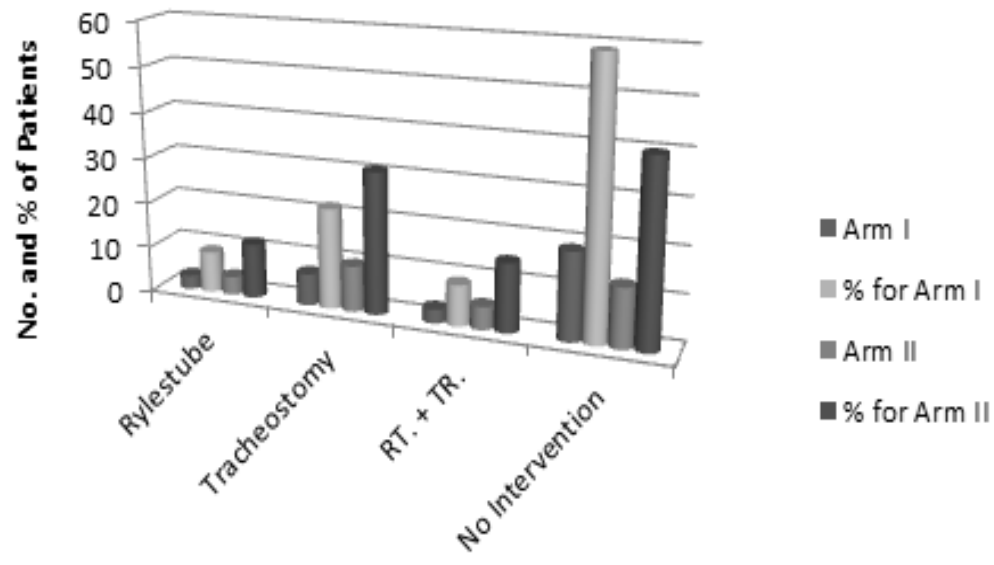

Figure 3. Incidence of Ryle's Tube Insertion/Tracheostomy on Patients

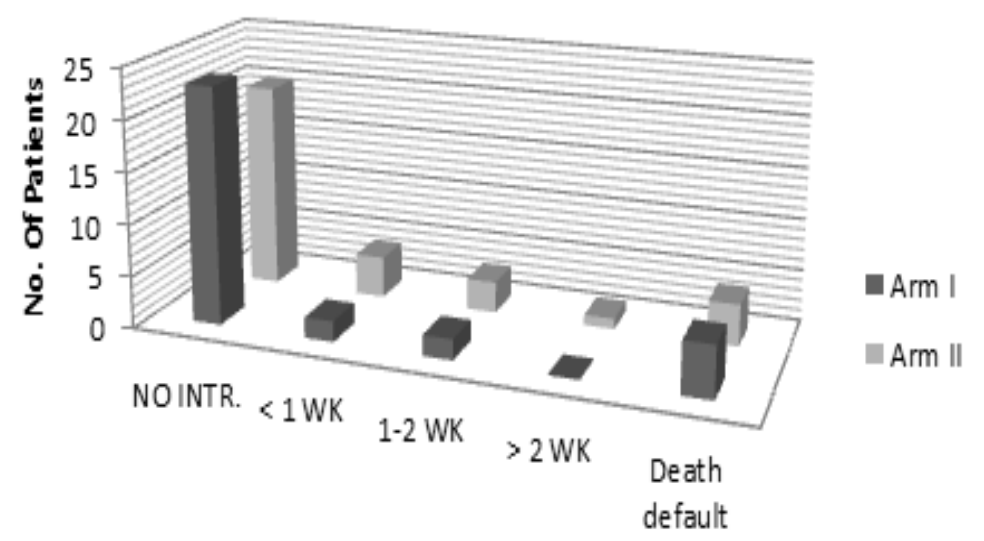

Figure 4. Showing no. of Treatment Breaks

after completion of radiotherapy. The response by Arm I was $31 \%$ with CR, $47 \%$ with PR, $6 \%$ with NR and $3 \%$ with DP whereas $6 \%$ ware default and $6 \%$ reported with death. Result for similar treatment by Arm II shows 12\% with CR, $15 \%$ with PR, $1 \%$ with NR and $0 \%$ with DP whereas $9 \%$ ware default and 3\% reported with death (Figure 2). Figure 3 shows the incidence of ryles tube Insertion/Tracheostomy. In Arm I, the intervention was reported for ryles tube in $9 \%$ patients, for tracheostomy in $22 \%$ patients, for both in $9 \%$ patients however no intervention was required in $59 \%$ of Patients. In Arm II, the intervention was reported for ryles tube in $12 \%$ patients, for tracheostomy in $31 \%$ patients, for both in $15 \%$ patients however no intervention was required in $40 \%$ of Patients. While overall treatment, interruption was required by 2 patients of Arm I and 4 patients of ArmII before completion of 1 week of treatment. By week 1 to week 2 of treatment, interruption was required by 2 patients of Arm I and 3 patients of ArmII. After 2 week only 1 patient of ArmII was interrupted. However the deaths and defaults were 5 patients in Arm I and 4 patient in Arm II. Hance, the results forward an ultimate advantage in tumour response with chemo boost arm on compared arm with conventional chemoradiotherapy.

\section{Discussion}

Our study aimed The study concluded that the loco-regional responses are analogous in Arm I and Arm 2, however Arm II had additional treatment allied toxicities and resulting from numerous of treatment breaks. A total of 64 patients were enrolled wherein 32 patients were randomly placed in each arm. The ratio of Male and Female patient was 31:1 in each arm. Maximum numbers of patients were of between 51-60 years of age group. Most patients with $31 \%$ of total patient had addiction of bidi/ cigarette smoking since 20 yrs (Table 1). The majority of patient with $78.1 \%$ of total patients belonged to rural Area (Table 1). In maximum number of cases, the stages 3 in $48.4 \%$ patients followed by stage 4 in $46.8 \%$ patients of all patients were reported. The response to treatment was assessed 2 months after completion of the radiotherapy (Table 2). The entire response in Arm I when compared to Arm II (31\%Vs 38\%) was establish insignificant having "P value" of 0.06 . The Acute toxicities were recorded when they occurred throughout treatment until 2 months not before finishing radiotherapy. On analysing acute skin reactions in both the arms, Maximum number of patients developed toxicities of Grade 2 during 3rd and 4th week of RT. Here the toxicities were higher in Arm II having "p-value" of 0.03 that is significant. On analysing the laryngeal reactions, maximum number of patient developed toxicities of Grade 2 during 4th week of RT. Here the toxicities were higher in Arm II with p-value of 0.03 that is significant. By Dysphagia analysis, Maximum number of patients developed 
the toxicities of Grade 2 during 3rd and 4th week of RT. The Toxicities were equivalent in both the Arm I and Arm II. The Salivary gland toxicities were analogous in both the Arms. On evaluating the Haematological toxicity in Arm, I: $22 \%$ of patient that is Maximum, developed grade 2 toxicities respectively during $3 \mathrm{rd}$ and $22 \%$ of patient that is Maximum, developed grade 2 toxicities respectively during 4th week of RT. In Arm II 34\% of patient that is maximum, developed Grade 2 toxicities respectively during $3 \mathrm{rd}$ and $40 \%$ of patient that is maximum, developed Grade 2 toxicities respectively during 4th weeks of RT. The Toxicities were higher in Arm II with significant $\mathrm{p}$ value of 0.04 . Regarding Ryle's tube / tracheotomy, intervention was not mandatory in 59\% of patient in Arm I and $40 \%$ of patient in Arm II. Interruption in treatment was not required in $72 \%$ of patient in Arm I and $62 \%$ of patients in Arm II.

In conclusion, the cancer larynx comprised of $11.28 \%$ of total head and neck cases and $4.99 \%$ of total cancer cases. The age group predominantly affected was between 51-60 yrs. however the ratio Male patients were more commonly affected than the female patients. Most patients were addict of bidi/ cigarette with period more than 20 yrs. The advanced stages of disease had been reported in $95 \%$ of patients (stages III and IV). There was an ultimate advantage in tumour response with chemo boost arm on compared arm with conventional chemoradiotherapy. The Results were $38 \%$ vs $31 \%$ ( $\mathrm{P}$ value not significant). The Acute reactions were more frequently observed in chemo boost arm and were severe enough to cause treatment breaks. The Ryle's tube insertions and tracheostomies were more often observed in chemo boost arm as compared to conventional group. As compared to conventional group the Treatment breaks were more common in chemo boost arms.

\section{Statement conflict of interest}

The authors declare no conflict of interest.

\section{References}

Allal AS, Zwahlen D, Becker M, Dulguerov P, Mach N (2006). Phase I trial of concomitant hyper fractionated radiotherapy with docetaxel and cisplatin for locally advanced head and neck cancer. Cancer J, 12, 63-8.

Allen AM, Elshaikh M, Worden FP, et al (2007). Acceleration of hyper fractionated chemoradiation regimen for advanced head and neck cancer. Head Neck, 29, 137-42.

Barbara RP, Alfred WR, Jerilyn AL, Muveddet DH, Bharat BM (2014). Comparison of swallowing function after intensity-modulated radiation therapy and conventional radiotherapy for head and neck cancer, Wiley Online Library, DOI: 10.1002/hed.23796.

Bose P, Brockton NT, Dort JC (2013). Head and neck cancer: From anatomy to biology. Int J Cancer, 133, 201323.

Browman GP, Hodson DI, Mackenzie RJ, et al (2001). Choosing a concomitant chemotherapy and radiotherapy regimen for squamous cell head and neck cancer: a systematic review of the published literature with subgroup analysis. Head Neck, 23, 579-89.

Ferlay J, Soerjomataram I, Ervik M, et al (2013). GLOBOCAN 2012 v1.0, Cancer incidence and mortality worldwide: IARC Cancer base No. 11. Lyon, France: International Agency for Research on Cancer; 2013. Available from: http://www. globocan.iarc. Fr, [Last accessed on 2014 Nov 09].

Kies MS, Haraf DJ, Rosen F, et al (2001). Concomitant infusional paclitaxel and fluorouracil, oral hydroxyurea, and hyper fractionated radiation for locally advanced squamous cell head and neck cancer. J Clin Oncol, 19, 1961-9.

Kitamoto Y, Akimoto T, Ishikawa H, et al (2005). Acute toxicity and preliminary clinical outcomes of concurrent radiation therapy and weekly docetaxel and daily cisplatin for head and neck cancer. Jpn J Clin Oncol, 35, 639-44.

Lefebvre JL, Chevalier D, Luboinski B, et al (1996). Larynx preservation in pyriform sinus cancer: preliminary results of a European organization for research and treatment of cancer phase III trial. EORTC Head and Neck Cancer Cooperative Group. J Natl Cancer Inst, 88, 890-9.

Moyer JS, Wolf GT, Bradford CR (2004). Current thoughts on the role of chemotherapy and radiation in advanced head and neck cancer. Curr Opin Otolaryngol Head Neck Surg, 12, 82-7.

Murphy BA (2011). Carcinomas of head and neck. In: Skeel RT, Khleif SN, editors. Handbook of Cancer Chemotherapy. 8th ed. New Delhi, India: Lippincott Williams and Wilkins, Wolters Kluwer (India) Pvt. Ltd, pp 69-93.

Robbins KT, Vicario D, Seagren S, et al (1994). A targeted supradose cisplatin chemoradiation protocol for advanced head and neck cancer. Am J Surg, 168, 419-22.

Rosen FR, Haraf DJ, Kies MS, et al (2003). Multicentre randomized phase II study of paclitaxel (1-hour infusion), fluorouracil, hydroxyurea, and concomitant twice daily radiation with or without erythropoietin for advanced head and neck cancer. Clin Cancer Res, 9, 1689-97.

Schwarz JK, Giese W (2004). Organ preservation in patients with squamous cancers of the head and neck. Surg Oncol Clin N Am, 13, 187-99.

Vokes EE, Stenson K, Rosen FR, et al (2003). Weekly carboplatin and paclitaxel followed by concomitant paclitaxel, fluorouracil, and hydroxyurea chemoradiotherapy: curative and organ-preserving therapy for advanced head and neck cancer. J Clin Oncol, 21, 320-6.

Waes CV, Haglund KE, Conley BA (2014). Head and neck cancer. In: Abraham J, Gulley JL, Allegra CJ, editors. The Bethesda Handbook of Clinical Oncology. 4th ed. Philadelphia, USA: Lippincott Williams and Wilkins, Wolters Kluwer Business; pp 130.

Weber RS, Berkey BA, Forastiere A, et al (2003). Outcome of salvage total laryngectomy following organ preservation therapy: the Radiation Therapy Oncology Group trial 91-11. Arch Otolaryngol Head Neck Surg, 129, 44-9.

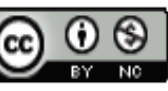

This work is licensed under a Creative Commons AttributionNon Commercial 4.0 International License. 